metallic carbides and hydrides, and the electric furnace is fully described. Three Beiträge zur Geschichte der Naturwissenschaften, numbered xi., xii., and xiii., are contributed by Prof. Eilhard Wiedermann, and a paper on the emission-spectra of cadmium and zinc vapours jointly with A. Pospielow. Papers on the atomic weights of rhodium and of palladium are contributed by $A$. Hüttlinger and by P. Haas, and papers on electrolysis by Gutbier and by Herzog; papers dealing with medical subjects are contributed by de la Camp, by Grünbaum, and by Jamin, and a mathematical paper appears under the name of Noether.

At the end of 1907 the society included fifty-one ordinary, fifty-four honorary, and seventy-eight corresponding members; nine meetings had been held, and sixteen papcrs had been read and discussed. The "yicld" of scientific work will bear comparison with that of many societies claiming a wider range of membership, but in view of the large variety of topics discussed and the small number of papers dealing with any one branch of science, it is at least doubtful whether the publicity attained can be sufficient to compensate for the heavy cost of setting up and printing; as a general rule, the disadvantages of local publication are so serious as to outweigh the advantages which arise from stimulating the local centres of research.

\section{THE INTERNATIONAL CONGRESS OF APPLIED CHEMISTRY.}

THE seventh International Congress of Applied Chemistry was opened on Thursday, May 27 , in the afternoon, at the Royal Albert Hall by the Prince of Wales, who was accompanied by the Princess. A very large gathering was present, and the Prince, who spoke as vicepatron, the King being patron, offered in His Majesty's name a most hearty welcome, and expressed the King's pleasure that the foreign delegates would be able to visit Windsor Castle. It is only recently that the Prince, as president of the Board of Trade Committee to deal with exhibitions, directed attention to the importance of scientific progress, and at the opening of the congress he accentuated the value of scientific progress in words of such importance that we reproduce a portion of his speech verbatim.

"The main object which you all have in view is, I assume, to discuss in your numerous sections the ma.ry topics of interest and importance that are continually arising owing to the marvellous discoveries which the science of chemistry, both pure and applied, is making from day to day. Those interested in some special branch meet in the different sections their confreres from other lands to their mutual benefit. . . . These conferences, whether of a scientific or of a more intimate character, between men living in distant lands, all working for the same object, although under different conditions, cannot but be favourable to the progress of science and of the industries to which many of you have devoted your lives, as well as to the general peace of the world. I fully appreciate the important part which chemistry plays in almost every branch of our modern industry. We all recognise that without a scientific foundation no permanent superstructure can be raised. Does not experience warn us that the rule of thumb is dead, and that the rule of science has taken its place-that to-day we cannot be satisfied with the crude methods which were sufficient for our forefathers, and that those great industries which do not keep abreast of the advance of science must surely and rapidly decline? On behalf of the Princess of Wales and for myself, I offer our cordial greetings to the members of the congress, and I earnestly trust that great results may accrue from your deliberations. I now have much pleasure in declaring the seventh International Congress of Applied Chemistry open."

Sir William Ramsay, in the course of his opening address, said it is impossible to draw a hard-and-fast line between scientific and technical chemistry. Above all, chemistry is a practical science, although in recent years it has more and more tended to become a branch of applied nlathematics. The chief difference between pure and applied science consists in a satisfactory answer to the question-all-important to the technical chemist-." Will it pay?" This, however, is irrelevant to the man of science. On the answer to this question the success of a process depends; but in its essence applied and industrial chemistry are one. This has hardly been realised in a practical way on this side of the Channel or even on the other side of the Atlantic. Our Continental friends have realised it and acted upon it under the conviction that the industrial prosperity of a nation can best be advanced by an alliance between the technical and practical workers, that is to say, between the university and the factory. Such congresses as the present can teach much, and if this lesson be learnt, then a valuable national asset will have been sained. It is often said that science knows no country, and the existence of this congress accentuates the proof of the saying. All the nations of the civilised world are represented, and have met together to discuss how best to develop the special branches of chemistry to which the members have devoted their lives.

Prof. Wiley, of America, said there is no more apt illuştration of the utility of chemistry than to say that if its principles were unknown and unapplied, teeming millions of the globe would be at this moment unclad and unfed. Sanitation is a chemical problem; pure food, pure air, pure water, which ensure activity of mind and body and cure disease, are also problems for the chemist.

Prof. Armand Gautier, of France, said that in the development of industrial science England and France are not the only, but the great leading nations-never enemies, but always rivals.

Prof. O. N. Witt, replying for Germany, said the field of applied chemistry extends in two directions. It includes the analysis scientifically and the control of commercial raw products, and also of finished products. It further includes the advance of the chemical industries which are concerned with them. The congresses promote friendly feeling and noble rivalry, and as a consequence obtain the patronage of the rulers of nations.

Prof. Paterno, of Italy, said that naturally the members responded witn enthusiasm to an invitation from the country which was the birthplace of Boyle, Black, Cavendish, Priestley, Dalton, Davy, Faraday, Graham, and Woollaston. Even in the noisy rush and turmoil of London life scientific men know how to find the necessary tranquility to carry out their scientific investigations.

Prof. Arrhenius, in replying for other delegates of foreign lands, spoke of England as the classical world of applied chemistry. In this country, particularly in London, successful efforts have been made to improve hygiene by the employment of chemical methods, with the result that among the large cities of the world London has the lowest death-rate.

Later in the afternoon sectional meetings were held to arrange the work for the succeeding days of the congress. The organisation of the sectional work was a matter of considerable difficulty owing to the large number of papers sent in. This was notably the case in the sections for organic chemistry, analytical chemistry, and electrochemistry, in each case the number considerably exceeding one hundred, while the actual time available for work only amounted to $18 \frac{\text { z }}{2}$ hours.

In several cases, where the subject was of interest to more than one section, joint meetings were held. A special case of this was a joint meeting of five sections to discuss the fixation of atmospheric nitrogen, when Hofrath Prof. Bernthsen, Prof. Birkeland, and Dr. N. Caro presented the subject from different points of view. This particular discussion attracted great attention, not only because of its enormous importance, but also because Prof. Bernthsen's address was experimentally illustrated.

The process of Birkeland and Eyde, in which the arc is drawn out into a thin disc by the means of powerful magnets, is well known, but that of the Badische Anilinund Soda-Fabrik had not been previously described in this country. An iron tube contains an insulated electrode at one end and itself acts as second electrode. At its formation the arc springs from the insulated electrode to an adjacent part of the iron tube which is only a few millimetres away. Air is, however, blown tangentially or with a rotary motion through the tube. This carries the ent of the arc along the wall of the tube, so that it ends at a 
considerable distance from the electrode or on a special electrode placed at the further end for this purpose. Commercially, arcs nearly eight yards long have been produced. The air passing up the tube through the arc thus becomes oxidised. Prof. Bernthsen showed such an arc about three-quarters of a metre long. It was struck in a glass tube which had a copper spiral running up its entire internal length, this being shown in a darkened room. The sight of Prof. Armstrong's lecture theatre at the Central Technical College crowded to suffocation was very striking. After the arc had been burning for about one minute, two large glass globes connected with the arc tube became filled with brown fumes of oxides of nitrogen.

Prof. Birkeland followed, and accentuated some points in connection with the Birkeland-Eyde process. Then $\eta_{r}$. $\mathrm{N}$. Caro described the cyanamide process, and claimed that it was the cheapest method for the fixation of atmospher. $\mathrm{c}$ nitrogen. It was easy to obtain ammonia directly fron cyanamide, and, furthermore, a host of chemical products could be made by using cyanamide as a starting product.

Mr. E. R. Taylor read a paper of great interest upon national and international conservation of water-power, a subject which is attracting considerable attention in America. It will also be remembered that at the annual mecting of the British Science Guild Sir William Ramsay also brought this matter forward, and a committee was appointed by the Guild to consider the matter.

The pollution of sea-water was discussed in the hygiene section by Prof. Kenwood and Mr. F. N. Kay-Menzies. Edible sea shell-fish reared or deposited in the neighbourhood of our shores are often exposed to dangerously contaminated sea-water; it is also questionable whether bathing in such water is not dangerous. The bacteria of typhoid can survive for several days in sea-water, and coastal tides and eddies are capable of carrying sewage contamination several miles in the course of twenty-four hours.

Dr. M. Frenkel described a method for rendering motorcar escape gas odourless. The car is fitted with a special box containing platinised asbestos or platinised porous porcelain. The exhaust gases are made to pass through this box, and the contact of the air and malodorous gas with the catalytic platinum causes complete oxidation, and thus deodorisation.

On Friday afternoon, May 28, Prof. Halle, of France, and Prof. Paternò, of Italy, gave addresses to the whole congress. On Monday, May 3I, Prof. O. N. Witt, of Germany, and on Tuesday, June I, Sir Boverton Redwood also gave addresses to the combined sections of the congress.

The congress was attended by more than 4000 members, and the number of papers presented was very large. The attendance at the sectional meetings was quite extraordinary, many members attending their particular section from 10 in the morning to 1.30 , and then from 4 to 6 in the evening, and listening to the reading of twenty or thirty papers ranging over the whole scope of the subject. In one section there were at $6 \mathrm{p} . \mathrm{m}$. more than 100 members alert and eager for more.

The hospitality has always been a feature of these congresses, and the countries in which the congresses have been held have vied with each other in the entertainment of their guests. In this respect also the congress in London was not behindhand. The members were entertained by the Lord Mayor and Sheriffs at the Guildhall on Wednesday, May 26, and on May 27 a reception was held at the Foreign Office by Mr. Lewis Harcourt, M.P., on behalf of the Government. About two thousand invitations were sent out; and the company bidden to meet the delegates included the French. Russian, Austro-Hungarian, Spanish, American, and Japanese Ambassadors; the Portuguese, Netherlands, Belgian, Brazilian, Swedish, Chinese, Greek. Norwegian, and Danish Ministers; leading members of the Government and the Opposition; and others of social and political distinction. Though most of the foreign members of the congress were present, apparently no effort was made to bring together British men of science of distinguished eminence in all departments of scientific activity to meet them. The visitors must have been disappointed to find that the chief people present at the reception, other than actual members of the congress, No. 2066 , VOL. 80$]$ were renowned for their political and diplomatic connections rather than by their position in the scientific world.

There was a great banquet at the Crystal Palace on May 28, which was held in the central transept, and to which nearly 2000 ladies and gentlemen sat down. The dinner was followed by speeches, which some heard, and then by a special display of fireworks, which all saw. On Saturday, May 29, the King received a deputation from the congress, who were accompanied by Sir Henry Roscoe (hon. president), Sir William Ramsay (acting president), and Mr. W. Macnab (hon. general secretary). The following delegates had the honour of being presented to the King by Sir Henry Roscoe:-Dr. W. H. Nichols (America), K.K. Regierungsrat F. Strohmer (Austria), Dr. François Sachs (Belgium), Mr. O. Kouanze (China), Prof. Leon Lindet (France), Prof. Otto N. Witt (Germany), Prof. E. Paterno (Italy), Prof. Kuhara (Japan), Dr. S. Hoogewerff (Netherlands), N. Tavildaroff (Russia), Prof. Pinerua y Alvarez (Spain), Prof. Arrhenius (Sweden), and M. F. Reverdin (Switzerland). On Saturday there was also a great garden-party at the Botanic Gardens, given by the ladies' committee, and in the evening a reception by the president of the Society of Chemical Industry. On Sunday and Monday there was a host of private parties, which absorbed nearly three thousand of the guests. Finally, on Tuesday, June 1, a reception was given at the Natural History Museum.

Such congresses cannot but help international goodwill and stimulate friendship between the nations. No jarring word was heard; delegates from all the civilised world fraternised, and each taught the other something of the work which is being done in their own country; friendly rivalry has been stimulated, and by means of the social functions they have learnt to know each other as friends. It is often said that international sport is a bond of friendship betwcen the nations, but it often leaves heartburnings. The meeting of a congress such as this leaves behind no unpleasant feeling, but stirs enthusiasm and admiration for the work which our rivals are carrying out, and cements the nations in a manner which no number of Dreadnoughts can accomplish.

\section{EDIJCATION AND RESEARCH IN APPLIED CHEMISTR Y.}

THE question of the training of industrial chemists, after having been dormant for some years, has again been raised, and it has now taken the more definite form of whether our universities should develop schools of applied chemistry. Let us look at the example of the engineering industries. There has been more coherence and solidarity and more personal interest on the part of the leaders of the engineering profession with regard to technical education than has been shown by chemical manufacturers. The practical effect is that the term "technical education" in Great Britain has become almost synonymous with training in engineering, and on the governing bodies of the newer institutions the engineering influence is predominant. The lack of active interest in the educational side of applied chemistry on the part of the manufacturers has acted detrimentally to their own cause. The teachers, if left alone by the manufacturers, are apt to become too purely bookish, and the manufacturers, if they cut themselves adrift from the academic side of chemistry, are likely to become too narrowly practical. The recent discussions upon the desirability of the better training of industrial chemists have centred round the universities, and the technical schools and technical colleges have been passed over.

\section{Definition of Terms.}

In many cases where the education of the technical or industrial chemist has been under discussion, the manufacturers on the one hand, and the teachers on the other, have had in view totally different kinds of people. When the training of an industrial chemist is under discussion, do we mean his preparatory general scientific education, or that plus something more? If the latter, what is that "something more" to be? The manufacturers who ex1 From the presidential address delivered before the Society of Chemica Industry on May 26, by Prof. Raphael Meldola, F.R.S. 